\title{
Pelaksanaan Sanksi dalam Mengatasi Tawuran Pelajar di SMK Kartika 1-2 Padang
}

\author{
Mira Laharisa, Henni Muchtar \\ Program Studi Pendidikan Pancasila dan Kewarganegaraan \\ Universitas Negeri Padang \\ E-mail: miralaharisa15@gmail.com
}

\section{ABSTRAK}

Penelitian ini bertujuan mengindentifikasi dan mendeskripsikan pelaksanaan sanksi dalam mengatasi tawuran pelajar di SMK Kartika 1-2 Padang. Penelitian ini menggunakan metode deskriptif yang mengambil lokasi di SMK Kartika 1-2 Padang. Alasan penulis memilih lokasi tersebut karena pelaksanan sanksi sanksi dalam mengatasi tawuran belum berjalan secara optimal. Penetapan informan dilakukan dengan puposive sampling. Teknik pengumpulan data dilakukan dengan cara observasi, wawancara, dan dokumentasi. Hasil penelitian menunjukkan bahwa pelaksanan sanksi dalam mengatasi tawuran pelajar di SMK Kartika 1-2 Padang meliputi 3 tahap diantaranya teguran. Teguran merupakan memberitahu dan memperingati seseorang dalam hal ini memperingati seorang pelajar bahwa tindakannya adalah tindakan yang salah dan diharapkan tidak akan mengulanggi lagi yang dilakukan oleh pihak sekolah SMK Kartika 1-2 Padang dalam mengatasi tawuran pelajar. Kedua, melakukan pemanggilan bagi pelajar yang melukan tawuran pelajar merupakan surat panggilan yang disampaikan oleh pihak sekolah SMK Kartika 1-2 Padang. Ketiga mengeluarkan siswa dari sekolah sebagai salah satu wujud dari nilai norma yang ada. Tujuan agar pelaksanan sanksi dalam mengatasi tawuran akan berjalan dengan baik.

Kata Kunci: sanksi, tawuran, pelajar

\section{ABSTRACT}

This research aims to identify and describe the implementation of sanctions in dealing with student brawls at SMK Kartika 1-2 Padang. This study uses a descriptive method that takes place in SMK Kartika 1-2 Padang. The reason the author chose the location is because the implementation of sanctions in dealing with brawls has not run optimally. Determination of the informant was done by purposive sampling. Data collection techniques carried out by observation, interviews, and documentation. The results showed that the implementation of sanctions in dealing with student brawls at SMK Kartika 1-2 Padang included 3 stages including reprimand. Reprimand is to inform and commemorate someone in this case commemorating a student that his actions are wrong and is expected to not be repeated by the SMK Kartika 1-2 Padang school in dealing with student brawls. Second is calling students who fight student brawls is a summons delivered by the SMK Kartika 1-2 Padang school. The last is expenditures of students from schools is a manifestation of the existing norm values in 
398 | Pelaksanaan sanksi..

schools called student discipline in SMK Kartika 1-2 Padang schools. The goal is that the implementation of sanctions in dealing with brawls will go well.

Keywords : sanction, brawls, student

(c) () (2) This work is licensed under the Creative Commons Attribution-ShareAlike 4.0 International License. @2019 (c) 


\section{PENDAHULUAN}

Pelajar merupakan
bagian dari individu yang
merupakan perubahan dari masa
transisi dari masa anak menuju
masa remaja hingga dewasa. Pada
tahap remaja sangat dibutuhkan
sosialisasi dengan masyarakat
disekitarnya. Pada tahap ini remaja
bersosialisasi dengan masyarakat
akan berdampak negatif maupun
positif. Menurut Oemar (2004: 99)
pelajar merupakan salah satu
komponen dalam pengajaran,
disamping faktor guru, tujuan dan
metode pengajaran. Dengan
demikian pelajar merupakan
seseorang yang mengembangkan
pontesi dalam dirinya melalui
proses pendidikan dan
pembelajaran pada jalur, jenjang
dan jenis pendidikan tertentu.

Pada saat ini, di berbagai media elektronik sering memberitakan tentang tawuran pelajar. Maraknya pemberitaan tawuran pelajar di berbagai media menyebabkan sekolah dari daerah lain ikut melakukan tawuran pelajar yang disebabkan oleh masalah siswa antar sekolah sehingga menyebabkan adu pendapat hingga tawuran antar pelajar. Tawuran pelajar merupakan salah satu perbuatan anak yang dapat dikategorikan sebagai kenakalan remaja atau juvenile deliquency. Tawuran pelajar menurut Kamus Besar
Bahasa Indonesia atau KBBI berasal dari kata "tawur" dan "pelajar". Tawur adalah perkelahian secara beramai-ramai, perkelahian masal, dan perkelahian yang terjadi secara tiba-tiba antara kedua belah pihak yang berselisih. Sedangkan tawuran pelajar adalah perkelahian yang dilakukan oleh sekelompok orang yang mana perkelahian tersebut dilakukan oleh orang yang sedang belajar.

$$
\text { Dampak dari tawuran }
$$
pelajar ini merugikan banyak pihak, terutama bagi sai pelaku. Pelaku akan mengalami cedera, bahkan tewas dalam tawuran tersebut. Bukan hanya itu tawuran pelajar tersebut juga berdampak seperti merusak fasilitas infrastruktur yang ada, seperti ruko, kendaraan, halte bus, dan sekolah.

SMK Kartika 1-2 Padang merupakan salah satu sekolah yang siswanya sering melakukan tawuran. Berikut data tawuran yang di dapat pada tanggal 5 Agustus 2019, terjadi peningkatan angka siswa yang tawuran dalam tiga tahun terakhir. Dari buku kasus SMK Kartika 1-2 Padang diketahui bahwa pada tahun 2016 sebanyak 25 pelajar yang melakukan tawuran. Kemudian pada 2017 sebanyak 32 pelajar yang melakukan tawuran. Sementara pada tahun 2018 sebanyak 40 
pelajar yang melakukan tawuran. Dari data tersebut dapat dilihat bahwa tawuran antar pelajar tidak dapat dianggap remeh. Sebab jika tidak ada penanganan secara serius oleh pihak terkait akan berdampak negatif terhadap kondisi pelajar, lingkungan sekolah dan lingkungan masyarakat. Oleh karena itu, perlu adanya kepastian dalam penegakan hukum yang dilakukan pihak sekolah untuk menindak lanjuti hukuman apa yang diberikan untuk pelaku tawuran pelajar tersebut sehingga ada efek jera dari si pelaku.

Dalam rangka mengurangi kasus tawuran pelajar, sebenarnya pihak sekolah telah memberikan sanksi bagi siswa yang terlibat dalam tawuran tersebut. Adapun sanksi yang diberikan kepada pelajar berupa surat peringatan pertama yakni teguran dari pihak sekolah seperti wali kelas, guru bimbingan konseling (BK) dan bapak/ibu wakil kesiswaan. Kedua sanksi berupa surat di atas materai yang berisi perjanjian untuk tidak mengulangi perbuatannya. Ketiga dengan cara memanggil orang tua dari siswa yang melakukan tawuran dan ada sebagian pelajar yang dikeluarkan dari sekolah dan melakukan surat perjanjian dihadapan orang tua. Dengan adanya sanksi tersebut maka diharapkan dapat memberikan efek jera bagi pelajar yang melakukan tawuran tersebut. Adapun data pelajar yang terkena sanksi dalam tiga tahun terakhir juga mengalami peningkatan. Pada tahun 2016 sebanyak 20 pelajar yang terkena sanksi dari sekolah, tahun 2017 sebanyak 30 pelajar dan pada tahun 2018 sebanyak 40 pelajar yang terkena sanksi. Melihat trend peningkatan tersebut semestinya pihak sekolah harus tegas dalam melaksanakan sanksi di sekolah dalam mengatasi tawuran pelajar di SMK Kartika 1-2 Padang.

Pihak sekolah telah membuat tata tertib seperti tertulis dalam buku tata tertib siswa tahun 2016-2017 di SMK kartika 1-2 Padang yang diberikan pada saat penerimaan siswa baru yang mengatur segala bentuk tindakan yang diharuskan dilakukan peserta didik saat melakukan aktifitas sekolah. Seperti dituliskan dalam bab V pasal poin ke 5 berhubungan dengan larangan membuat keonaran/tindakan kriminal di dalam lingkungan sekolah maupun diluar lingkungan sekolah yang berpengaruh buruk dan dapat mencemarkan nama baik sekolah. Kemudian poin ke 8 yang dapat memicu tindakan kekerasan berupa tawuran yang berbunyi larangan membawa senjata tajam, senjata api, atau sejenisnya yang tidak ada hubungannya dengan pendidikan. Adapun sanksi terhadap tawuran belum dilakukan sesuai dengan 
tata tertib sekolah sebagai berikut pemberian pembinaan skorsing bagi pelajar yang melakukan tawuran dan tidak naik kelas bagi pelajar yang melakukan tawuran.

Penelitian ini penulis laksanakan karena ingin melihat bagaimana pelaksanaan sanksi dalam mengatasi tawuran pelajar di SMK Kartika 1-2 Padang. Penulis melihat bahwa pelaksanaan sanksi dalam mengatasi tawuran pelajar di sekolah tersebut kurang berjalan dengan baik. Alasan penulis memilih SMK Kartika 1-2 Padang sebagai saran penelitian karena belum pernah dilakukan penelitian mengenai pelaksanaan sanksi dalam mengatasi tawuran pelajar di SMK Kartika 1-2 Padang.

\section{METODE PENELITIAN}

Metode yang digunakan dalam penelitian ini adalah penelitian kualitatif dengan metode deskriptif. Lokasi penelitian di SMK Kartika 1-2 Padang. Informan penelitian yaitu Kepala Sekolah, Wakil Kesiswaan, guru, siswa dan orang tua murid yang melakukan tawuran. Jenis data yang digunakan yaitu Data Primer dan Data Sekunder. Teknik pengumpulan data meliputi observasi, wawancara dan dokumentasi dengan menggunakan alat pengumpulan data seperti pedoman wawancara, handphone serta buku catatan.
Sedangkan teknik pengujian keabsahan datanya menggunakan teknik triangulasi sumber data dan yang terakhir teknik analisis data dengan cara pengumpulan data, reduksi data, penyajian data dan penarikan kesimpulan.

\section{HASIL DAN PEMBAHASAN}

Menurut teori yang diutarakan oleh Sidik Pramono dalam bukunya gank sekolah (2009:4) faktor penyebab tawuran antara lain adalah dendam antar pelajar yang merupakan balasan atas perlakuan/tindakan merugikan yang dilakukan oleh pelajar yang lain. Teori ini dapat dibuktikan kebenarannya bahwa salah satu alasan gank sekolah SMK Kartika 1-2 Padang melakukan tindakan membela diri/balas dendam atas perlakuan kurang enak yang dilakukan oleh pelajar lain demi menjaga solidaritas antar teman sekaligus menjunjung tinggi nama baik sekolah. Menurut Kartono (2010:110-128), penyebab terjadinya tawuran ada dua yaitu mencakup faktor internal dan faktor eksternal. Faktor internal meliputi reaksi frustasi negatif serta gangguan emosional pada remaja.

Sedangkan faktor eksternal meliputi faktor keluarga yang kurang memperhatian anak maupun lingkungan sekolah tidak menguntungkan/ kondusif. Di SMK Kartika 1-2 Padang juga 
ditemui beberapa anak yang memang secara fisik dinyatakan sehat namun secara mental/ psikis mereka sedikit terganggu karena merasa senang apabila dapat melakukan tindakan tawuran pelajar dan melukai siswa sekolah lain maupun berlaku/ bertindak melecehkan orang dengan cara verbal meliputi ejekan ejekan maupun umpatan.

Para orang tua sudah sangat percaya dengan pola pendidikan sekolah sehingga kurang melakukan kontrol terhadap anak. Padahal seharusnya orangtua mempunyai andil yang cukup besar dalam perilaku anak karena sekolahpun apabila anak tidak diberi pondasi yang kuat pasti akan terpengaruh oleh hal-hal negatif. Terdapat faktor lain yang menyebabkan terjadinya tindakan tawuran, namun presentasenya sangat kecil untuk menjadi pemicu tindakan tawuran antara lain yaitu rebutan pacar dan vandalisme.

Dampak tindakan tawuran juga berimbas pada vadalisme/coret-coretan yang dilakukan oleh siswa terhadap tembok kelas, tembok disekitar lapangan, pintu kamar mandi maupun meja dan kursi di dalam kelas. Hal tersebut terlihat dari hasil observasi peneliti ketika mengamati seluruh lingkungan sekolah. Selain itu pada tanggal 28 juni 2019 peneliti 2019 peneliti melihat beberapa siswa yang mengenakan baju tidak rapi dan tidak sesuai dengan aturan misalnya tidak memakai sepatu hitam, tidak mengenakan ikat pinggang selain itu juga masih ditemukan siswa yang berbicara kotor ketika berada di lingkungan sekolah.

Ditembok- tembok sekolah baik di dalam maupun diluar sekolah banyak coretan yang dilakukan oleh SMK Kartika 1-2 Padang maupun oknum siswa lain. Vandalisme yang berada di luar sekolah dapat memicu tawuran antar pelajar dengan sekolah lain. Karena setiap sekolah mempunyai identitas nama gank sendiri-sendiri dan apabila dicoret maka itu dianggap sebagai pelecehan/penghinaan sekolah yang bersangkutan.

Dalam rangka mengurangi intensitas tawuran pelajar di SMK Kartika 1-2 Padang sekolah telah membuat tata tertib sekolah. Tata tertib sekolah berisi tentang larangan, perintah dan poin sanksi terhadap setiap pelanggaran siswa. Sekolah selalu memberikan sanksi yang sifatnya mendidik kepada siswa yang melakukan pelanggaran tata tertib khususnya tawuran pelajar dengan memberikan efek jera. Sebagai seorang pendidik tentunya tata 
tertib bukanlah hal yang mutlak, sehingga tetap harus disesuaikan dengan situasi dan kondisi yang terjadi disekolah. Sekolah membuat beberapa tahap dalam mengurangi tingkat tawuran pelajar yang ada di SMK Kartika 1-2 Padang.

Peraturan terkait kenakalan remaja terdapat dalam pasal 170 dan pasal 358 KUHP berkenaan dengan peristiwa tawuran (perkelahian beramai-ramai dan menganggu ketertiban/ meresahkan masyarakat, baik mengakibatkan terjadinya korban (luka-luka luka berat, mati atau kerusakan barang) maupun yang tidak memakan korban, lebih dikenakan pasal $170 \mathrm{KUHP}$, yang berbunyi 1) barang siapa dengan terang-terangan dan dengan tenaga bersama menggunakan kekerasan terhadap orang atau barang, diancam dengan pidana penjara paling lama lima tahun enam bulan; 2) yang bersalah diancam : dengan pidana penjara paling lama tujuh tahun, jika ia dengan sengaja menghancurkan barang atau jika kekerasan yang digunakan mengakibatkan luka-luka, (b) dengan pidana pejara paling lama sembilan tahun, jika kekerasan mengakibatkan luka berat; (c) dengan pidana penjara paling lama dua belas tahun, jika kekerasan mengakibatkan maut. Berdasarkan pasal 358 KUHP, berbunyi a) dengan pidana penjara paling lama dua tahun delapan bulan, bila akibat penyerangan atau perkelahian itu ada yang luka-luka berat; b) dengan pidana penjara paling lama empat tahun bila akibatnya ada yang mati.

\section{SIMPULAN}

Berdasarkan hasil pembahasan dan analisis dalam penelitian ini, diperoleh kesimpulan bahwa faktor penyebab tawuran antara lain adalah dendam antar pelajar yang merupakan balasan atas perlakuan/tindakan merugikan yang dilakukan oleh pelajar yang lain. Penyebab terjadinya tawuran ada dua yaitu mencakup faktor internal dan faktor eksternal. Faktor internal meliputi reaksi frustasi negatif serta gangguan emosional pada remaja. Sedangkan faktor eksternal meliputi faktor keluarga yang kurang memperhatikan anak maupun lingkungan sekolah tidak menguntungkan. Di SMK Kartika 1-2 Padang juga ditemui beberapa anak yang memang secara fisik dinyatakan sehat namun secara mental atau psikis mereka sedikit terganggu karena merasa senang apabila dapat melakukan tindakan tawuran pelajar dan melukai siswa sekolah lain maupun berlaku atau bertindak melecehkan orang dengan cara verbal meliputi ejekanejekan maupun umpatan. Terkait dengan perkembangan anak, seolah-olah orang tua sudah sangat 
percaya dengan pola pendidikan sekolah sehingga kurang melakukan kontrol terhadap anak.

Dalam rangka mengurangi inttensitas tawuran pelajar di SMK Kartika 1-2 Padang, sekolah telah membuat tata tertib sekolah. Tata tertib sekolah berisi tentang larangan, perintah dan poin sanksi terhadap setiap pelanggaran siswa. Sekolah selalu memberikan sanksi yang sifatnya mendidik kepada siswa yang melakukan pelanggaran tata tertib khususnya tawuran pelajar dengan memberikan efek jera. Sebagai seorang pendidik tentunya tata tertib bukanlah hal yang mutlak, sehingga tetap harus disesuaikan dengan situasi dan kondisi yang terjadi disekolah.

\section{DAFTAR PUSTAKA}

Oemar, Hamalik. 2008. Kurikulum Dalam Pembelajaran. Jakarta. Sinar Grafika

Kartono, Kartini.2010.Patologi Sosial

2 Kenakalan Remaja. Jakarta. Pt Grafindo.

Kartono, Kartini. 2013. Kenakalan Remaja. Jakarta. Pt Grafindo. Undang-Undang Republik Indonesia Nomor 23 Tahun 2002. Tentang Perlindungan Anak Undang-Undang Republik Indonesia Nomor 11 Tahun 2012. Tentang Sistem Peradilan Anak. http:// Antaranews.com/ berita 322987/tawuran pelajar meningkat.

http:// sp .beritasatu.com / home/45225 pada tanggal 20 juli 2014.

http:/ / edukasi.compas.com / read /2011/12/23/10210953/. Pada tanggal 27 mei 2014. 